\title{
An investigation on effects of perceived value on brand popularity and brand loyalty: A B2B case study
}

\author{
Zakaria Karimi Rad $^{\mathrm{a}^{*}}$, Seyyed Majid Elahi ${ }^{\mathrm{b}}$ and Morteza Gholami Tazeabad ${ }^{\mathrm{c}}$
}

${ }^{a}$ Student of MBA at Imam Khomeini International University, Qazvin, Iran.

${ }^{b}$ Assistant Professor at Imam Khomeini International University, Industrial Management Faculty, Qazvin, Iran

${ }^{c}$ Student of Master of Financial Engineering at University of Science and Culture, Tehran, Iran

\section{CHRON I C LE ABSTRACT}

\section{Article history:}

Received October 30, 2013

Received in revised format

30 November 2013

Accepted 9 January 2014

Available online

January 202014

Keywords:

Perceived Value

Risk

Brand popularity

Brand Loyalty

$B 2 B$

\begin{abstract}
This research evaluates the effect of perceived value on brand popularity and brand loyalty for some organizations in business-to-business (B2B) domain under the effect of risk and e-service quality. The practical relationships among six different kinds of risks including performance, social, financial, time, psychological and safety with consideration of quality in e-commerce business on customer's perceived value are evaluated and the effects of this perception of value on consequences of perceived value are measured. In this study, using the partial least square method as well as gathering the information of some Iranian firms that use electronic services, the study finds that there was a significant relationship between various types of risks and perceived value. There is also considerable influence of perceived value on satisfaction, brand popularity, and brand loyalty.
\end{abstract}

\section{Introduction}

The effect of electronic services and devices, in the management decisions and in infrastructure of organizations within business-to-business (B2B) domain is completely apparent and many scholars have examined it (Day \& Bens, 2005). Besides, electronic services are considered as key elements of development in organizations, which are associated with these kinds of services (Molinari et al., 2008). The customer perceived value has been explained as the main instrument of competitive strategies and the heart of management approaches by the researchers (Fortuin \& Omta, 2007; Brennan \& Henneberg, 2008). In addition, the customers' perceived value is closely associated with marketing technique and customer-oriented nature of an organization (Brennan \& Henneberg, 2008). Therefore, we cannot neglect the essential role of these services in future of business units. Although

*Corresponding author. Tel: +98 9126089310 Fax: +98 2177631473

E-mail addresses: raadz13@gmail.com (Z. Karimi Rad) 
there is not enough study in Iran, we see more and more organizations are interested in applying these services and great opportunities in making profit in these areas exist. In this study, electronic services are all of the applications of internet, e-banking, e-business, etc. in B2B domain within organizations. We also enter risk as a key factor of decision making in companies (Kumar \& Grisaffe, 2004). Risk is one of the most probable items of outcome and extremely influential in cost of ultimate outcome (Dwyer \& Tanner, 2009). According to what comes so far and based on the Sweeney et al. (1999) who examined all perspectives of risk in their study, risk is one of the determinants of perceived value. Note that customers' perceived value, as a dependent variable and satisfaction are reflective concepts (Haenlein \& Kaplan, 2004). Satisfaction with its obvious meaning has a direct association with customer's perceived value. In other words, if a product or a service has a value for customer, he/she will be satisfying with and vice versa. Philip Kotler adopted the definition of customer delivered value, namely obtaining the total value of customer, including product value, service value, personnel value and image value, minus paying the total cost of customer, including price, time cost, energy cost and physical cost equals to the difference. Customer value is the difference between the value obtained from a product of customer possession and the cost paid in order to receive a product (Sun \& Su, 2012; Kotler, 1998).

For decades, brands have been considered as crucial parts of firms for building relationships with consumers assuring long-term business success (Tuškej et al., 2013). The importance of building strong brands as an imperative strategy to succeed in highly competitive environments has increasingly emphasized in the brand management field of the marketing research (Morrison \& Crane, 2007). Therefore, we consider brand popularity as one of the outcomes of satisfaction in this study. Finally, brand loyalty is another outcome of satisfaction, which defines penchant of customer to other suppliers and manufactures of products and services (Fiol et al., 2011).

Brand popularity reflects the number of brand fans, which gives an indication of the brand's recognition on social media (de Vries et al., 2012). Previous researches have suggested that brands have an important effect on product selection and customer choice; especially in face of uncertainty about product attributes and/or their advantages (Erde et al., 2002; Huang \& Dubinsky, 2004). de Vries et al. (2012) reported that within industry market consumers become brand fans because they have had a positive experience with the product (Van Belleghem, 2010; de Vries et al., 2012). In this study, we examine the effects of risk on perceived value of customer (organization) and measure its ultimate impact on customers' behavior in electronic commerce. To the best of our knowledge, this is first time that effect of customers' perceived value on brand popularity is studied and we hope it gves some insights to other researchers for further examinations.

\section{Theoretical background}

The conceptual framework of this research is based on what Faroughian et al. (2012) accomplished shown in Fig 1. In this model, we see direct relationship among different kinds of risk and quality of electronic services with perceived value. Then, the relationship of perceived value and satisfaction are depicted and finally influence of satisfaction on brand popularity and brand loyalty is outlined (Faroughian et al., 2012). Different scholars do complete review of definition of customer value and its historical background (Woodall, 2003; Bolton et al., 2000; Anderson \& Narus, 1998; Woodruff, 1997; Ravald \& Grönroos, 1996). Zeithaml (1988) did the same research about quality and its effect on perceived value. Get and give are two components of perceived value and subtraction of them provides customers' perceived value. Get is whatever customer leaves for the services or products like money, time, etc. and give is whatever customer gains in order to use of services and products. There some evidences that if the "gives" is much greater than the "gets", then customers experience the large amount of perceived value. Although this concept is rational and based on economic rules, it neglects some other important and complex parameters like aesthetics and hedonic aspects of buying process and customers behavior that is directly influential on customers' mind (Walker et al., 2006). 
In this study, we consider "experience", "social image", "cost of change", "convenience" and "price" as latent variables of perceived value (Fiol et al., 2011).

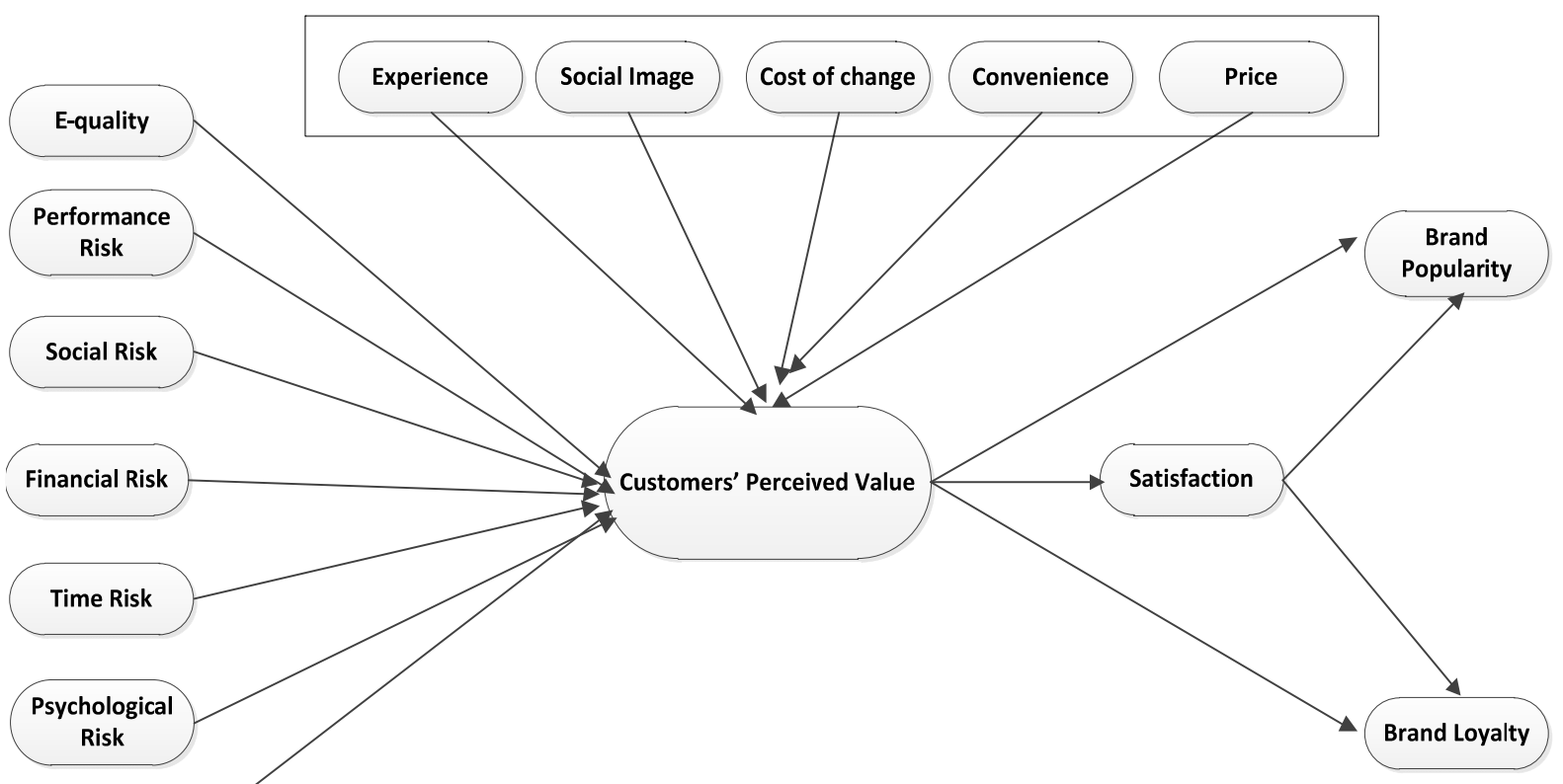

Safety Risk

Fig. 1. Conceptual framework

There are seven hypotheses for the proposed study of this paper. First, impact of quality on perceived value is studied. We expect that quality influences on customers' perceived value, positively. In addition, customer perceived value of services rendered, just as he/she perceived the quality of service offered by the business. Customer value is created because this perception should be considered as the fundamental basis of a long-term sustainable marketing relationship (Yaşlığlu et al., 2013).

$\mathrm{H}_{1}$ : Better quality of e-service in positive effect on perceived value.

$\mathrm{H}_{2}$ : Performance risk has a negative effect on perceived value.

$\mathrm{H}_{3}$ : Social risk has a negative effect on perceived value.

$\mathrm{H}_{4}$ : Financial risk has a negative effect on perceived value.

$\mathrm{H}_{5}$ : Time risk has a negative effect on perceived value.

$\mathrm{H}_{6}$ : Psychological risk has a negative effect on perceived value.

$\mathrm{H}_{7}$ : Safety risk has a negative effect on perceived value.

According to Featherman and Pavlou (2003), "perceived risk is commonly thought of as felt uncertainty regarding possible negative consequences of using a product or service." In this research, we examine comprehensive effect of perceived risk on perceived value since it is a significant parameter in a consumer behavior and buyers decisions (Roselius, 1971). We use six constructs of perceived risk: (1) performance, (2) social, (3) financial, (4) time, (5) psychological and (6) safety in this research (Cunningham, 1967). According to Zhang et al. (2012) and Crespo et al. (2009) Performance risk can be considered as the possibility of the product mal-functioning and performing improperly as it is originally designed and advertised, which leads us to have undesired benefits. Social risk is potential loss of status in one's social group because of receiving a particular product or service, looking foolish or untrendy. Financial risk is the potential monetary outlay related to the initial buying price as well as the subsequent maintenance expenses of the product, and the potential financial loss due to possible fraud. Time risk is the other potential loss of time related to making a 
bad buying decision by wasting time researching, shopping, or replacing the unexpected product. Psychological risk is another potential loss of self-esteem from the frustration of not reaching a buying objective. Finally, safety risk is the potential loss of control over personal information, such as when information is used without our knowledge or permission.

There are many studies about impact of perceived value on satisfaction (Carpenter, 2008) and fewer studies have examined the effect of perceived value on brand popularity and brand loyalty. In this research, in addition to stated relationships, we have examined separate impact of satisfaction on brand popularity and brand loyalty (Jakobowicz \& Derquenne, 2007).

$\mathrm{H}_{8}$ : Perception of perceived value influences on brand popularity, positively.

$\mathrm{H}_{9}$ : perception of perceived value influences on customer satisfaction, positively.

$\mathrm{H}_{10}$ : perception of perceived value influences on brand loyalty, positively.

$\mathrm{H}_{11}$ : Satisfaction has a positive effect on brand popularity.

$\mathrm{H}_{12}$ : Satisfaction has a positive effect on brand loyalty.

According to Woodall (2003), value has a long-term construct for customers and it includes prepurchase, experience of buying, post-purchase and after that experience. Therefore, it is recommended that companies examine these impacts after few years of entrance to market.

\section{Methodology}

In this study, target population includes all companies and organizations that use e-service in city of Tehran, Iran. These companies have a kind of communication with other suppliers of e-service, other suppliers of materials for their products, other customers companies, and other partners. Based on literatures and our perceptual framework, we have designed a questionnaire in Likert scale of 1-5 from "strongly disagree" to "strongly agree" to measure the effect of all items. The sample size is calculated as follows,

$N=Z_{\alpha / 2}^{2} \frac{p \times q}{e^{2}}$,

where $N$ is the sample size, $p=1-q$ represents the probability, $z_{\alpha / 2}$ is CDF of normal distribution and finally $\varepsilon$ is the error term. For our study we assume $p=0.5, z_{\alpha / 2}=1.96$ and $e=0.05$, the number of sample size is calculated as $N=96$. We have distributed 100 questionnaires and collected 67 completed ones. The questionnaire completely covers diverse services of a routine usage of e-services in Iran including different kinds of e-service like internet and its infrastructure, short message service (SMS) panels, interactive voice response systems, influence of web sites and blogs in buying and selling products, smart phone and tablet's application and other types of services in virtual world. All of the companies in this survey had some degrees of involvement with e-services and had a bright insight of opportunities and limitations of this area (Aibinu \& Al-Lawati, 2010).

The first thing to measure is the validity of questionnaires with Cronbach's alpha. Based on literatures if a questionnaire has Cronbach's alpha of greater than 0.7 , it shows that questionnaire is satisfactory and valid (Bland \& Altman, 1997). Table 1 shows Cronbach's alpha and the number of questions that companies answered. A number for 0.930 is calculated for Cronbach alpha, which exhibits that our questionnaire is valid.

Table 1

Result of questionnaire's analysis

\begin{tabular}{ccc}
\hline Cronbach's alpha & Cronbach's alpha based on standardize questions & Number of questions \\
\hline 0.930 & 0.933 & 31 \\
\hline
\end{tabular}




\section{Analysis and results}

In this study, we use partial least square method and PLS-Graph software for analyzing our model. This approach has a diverse usage in different field of humanities (Wu, 2010:24). According to Chin et al. (1996), the PLS procedure has been receiving interest and popularity among information system researchers in recent years because of its features to model latent constructs under conditions of nonnormality and small to medium sample sizes. Partial least square is an old approach like LISREL. This approach as Chin (1997), the programmer of PLS Graph, believes is not popular because it had not any software for analyzing models. In this study, we use PLS Graph for calculating regression coefficient, determination coefficient and other factors. In our model, brand popularity and brand loyalty have reflective structure, but dimensions of perceived value have a formative structure (Haenlein \& Kaplan, 2004; Gary \& Terry, 2003).

Results of the analysis are shown in Table 2. As we can observe, there is a positive and significant impact from e-service quality on perceived value. All types of the risks have negative impacts on perceived value expect psychological one and social risk that have a reverse impact on customer perception. Then, influence of perceived value on satisfaction and brand popularity and brand loyalty have shown that there was significant and positive relationship between these two components. If we see the results, we find that $\mathrm{R}^{2}=0.90$ for perceived value and with satisfaction and this shows a relatively high dependency between these two variables. On the other hand, $\mathrm{R}^{2}=0.34$ for the relationship between social risk and perceived value that shows this impact is less reliable.

\section{Table 2}

Result of PLS software

\begin{tabular}{ccccc}
\hline & \multicolumn{2}{c}{ Structural pathways } & Standardized path & ${\text { Contribution to } \mathrm{R}^{2}}$ \\
\hline $\mathrm{H}_{1}$ & e-Service quality & perceived value & $0.645(6.50)$ & 0.85 \\
$\mathrm{H}_{2}$ & performance risk & perceived value & $0.357(2.15)$ & 0.67 \\
$\mathrm{H}_{3}$ & social risk & perceived value & $-0.153(0.80)$ & 0.34 \\
$\mathrm{H}_{4}$ & financial risk & perceived value & $0.308(2.05)$ & 0.74 \\
$\mathrm{H}_{5}$ & time risk & perceived value & $0.455(2.55)$ & 0.78 \\
$\mathrm{H}_{6}$ & psychological risk & perceived value & $-0.048(1.43)$ & 0.51 \\
$\mathrm{H}_{7}$ & safety risk & perceived value & $0.113(1.95)$ & 0.62 \\
$\mathrm{H}_{8}$ & perceived value & brand popularity & $0.441(3.83)$ & 0.81 \\
$\mathrm{H}_{9}$ & perceived value & satisfaction & $0.835(5.85)$ & 0.90 \\
$\mathrm{H}_{10}$ & perceived value & brand loyalty & $0.743(5.27)$ & 0.79 \\
$\mathrm{H}_{11}$ & satisfaction & brand popularity & $0.367(2.95)$ & 0.70 \\
$\mathrm{H}_{12}$ & satisfaction & brand loyalty & $0.587(4.54)$ & 0.73 \\
\hline $\mathrm{P}<0.05$ & & & & \\
\hline
\end{tabular}

As we discussed before we consider "experience", "social image", "cost of change", "convenience", and "price" as latent formative variables of perceived value. The result of these latent variables of our model is illustrated in Table 3.

Table 3

Result of latent formative variables

\begin{tabular}{cc}
\hline Pathways & Standardized path coefficients (t-value) \\
\hline experience & $0.683(3.85)$ \\
social image & $0.233(2.10)$ \\
cost of change & $0.685(4.86)$ \\
convenience & $0.086(0.85)$ \\
price & $0.723(5.97)$ \\
\hline $\mathrm{P}<0.05$ &
\end{tabular}




\section{Discussion and further research}

During the past few years, e-service quality obviously is the initial step to gain goals and visions of management perspective. Quick access, safe environment, convenient interface design, and specific instructions for use are important determinants of quality of electronic services. In this study, because of the relative importance of safety, availability, infrastructure and other crucial factors of e-services, we have examined the impact of all of six types of risks in literature on perceived value of customers. In our survey, time, and financial risk were the most influential kinds of risks influencing on value, while psychological risk and social risk were considered as inconsequential kinds of risks. In addition, we have found that perceived value had diverse effect on brand popularity, satisfaction, and brand loyalty. The impact of perceived value on satisfaction was bigger than brand loyalty and impact of brand loyalty was greater than brand popularity. This research also has indicated that if an organization plans to increase its customers, it is necessary to focus on customers' perception of value and then on their satisfaction, because we see stronger relationship between perceived value and brand popularity and brand loyalty than between satisfaction and dimensions of brand. We can also conclude that customer perception of value and satisfaction had bigger impact on brand loyalty than brand popularity and we could conclude that brand loyalty was more important than brand popularity for customers. Moreover, if companies are looking for great-perceived value of their customers, they need to focus on the price of their products and services as the most critical dimension of perceived value.

Future work in this area that can develop this model to new levels are associated with expanding dimensions of perceived value and entrance of other parameters like brand image, emotion, trust and other aesthetic and hedonic aspects of purchasing and decision making into the model. Finally, we really look forward to expanding our survey to other international companies working in Iranian markets and other Iranian organizations that are new in the e-commerce market.

\section{References}

Aibinu, A. A., \& Al-Lawati, A. M. (2010). Using PLS-SEM technique to model construction organizations' willingness to participate in e-bidding. Automation in Construction, 19(6), 714-724.

Anderson, J. C., \& Narus, J. A. (1998). Business marketing: understand what customers value. Harvard business review, 76, 53-67.

Bland, J. M., \& Altman, D. G. (1997). Statistics notes: Cronbach's alpha. Bmj, 314(7080), 572.

Bolton, R. N., Kannan, P. K., \& Bramlett, M. D. (2000). Implications of loyalty program membership and service experiences for customer retention and value.Journal of the academy of marketing science, 28(1), 95-108.

Brennan, R., \& Henneberg, S. C. (2008). Does political marketing need the concept of customer value?. Marketing Intelligence \& Planning, 26(6), 559-572.

Carpenter, J. M. (2008). Consumer shopping value, satisfaction and loyalty in discount retailing. Journal of Retailing and Consumer Services, 15(5), 358-363.

Chin, W. W. (1997). Overview of the PLS Method. University of Houston.

Chin, W., Marcolin, B., \& Newsted, P. (1996). A partial least squares latent variable modeling approach for measuring interaction effects: results from a Monte Carlo simulation study and voice mail emotion/adoption study.

Crespo, A. H., del Bosque, I. R., \& de los Salmones Sanchez, M. G. (2009). The influence of perceived risk on Internet shopping behavior: a multidimensional perspective. Journal of Risk Research, 12(2), 259-277.

Cunningham, S. M. (1967). The major dimensions of perceived risk. Risk taking and information handling in consumer behavior, 82-108.

Day, G. S., \& Bens, K. J. (2005). Capitalizing on the internet opportunity.Journal of Business \& Industrial Marketing, 20(4/5), 160-168. 
De Vries, L., Gensler, S., \& Leeflang, P. S. (2012). Popularity of brand posts on brand fan pages: an investigation of the effects of social media marketing.Journal of Interactive Marketing, 26(2), 8391.

Erdem, T., Swait, J., \& Louviere, J. (2002). The impact of brand credibility on consumer price sensitivity. International Journal of Research in Marketing,19(1), 1-19.

Faroughian, F. F., Kalafatis, S. P., Ledden, L., Samouel, P., \& Tsogas, M. H. (2012). Value and risk in business-to-business e-banking. Industrial Marketing Management, 41(1), 68-81.

Featherman, M. S., \& Pavlou, P. A. (2003). Predicting e-services adoption: a perceived risk facets perspective. International Journal of Human-Computer Studies, 59(4), 451-474.

Fiol, L. J. C., Tena, M. A. M., \& García, J. S. (2011). Multidimensional perspective of perceived value in industrial clusters. Journal of Business \& Industrial Marketing, 26(2), 132-145.

Fortuin, F. T., \& Omta, S. W. F. (2006, January). Aligning R\&D to Business Strategy: A Longitudinal Study from 1997 to 2002. In System Sciences, 2006. HICSS'06. Proceedings of the 39th Annual Hawaii International Conference on(Vol. 8, pp. 189b-189b). IEEE.

Gary, F. T., \& Terry, A. B. (2003). Determinants of the relative advantage of a structured SDM during the adoption stage of implementation. Information Technology and Management, 20, 409428.

Haenlein, M., \& Kaplan, A. M. (2004). A beginner's guide to partial least squares analysis. Understanding statistics, 3(4), 283-297.

Huang, W. Y., Schrank, H., \& Dubinsky, A. J. (2004). Effect of brand name on consumers' risk perceptions of online shopping. Journal of Consumer Behaviour, 4(1), 40-50.

Jakobowicz, E., \& Derquenne, C. (2007). A modified PLS path modeling algorithm handling reflective categorical variables and a new model building strategy. Computational Statistics \& Data Analysis, 51(8), 3666-3678.

Kumar, A., \& Grisaffe, D. B. (2004). Effects of extrinsic attributes on perceived quality, customer value, and behavioral intentions in B2B settings: a comparison across goods and service industries. Journal of Business to Business Marketing, 11(4), 43-74.

Molinari, L. K., Abratt, R., \& Dion, P. (2008). Satisfaction, quality and value and effects on repurchase and positive word-of-mouth behavioral intentions in a B2B services context. Journal of Services Marketing, 22(5), 363-373.

Morrison, S., \& Crane, F. G. (2007). Building the service brand by creating and managing an emotional brand experience. Journal of Brand Management, 14(5), 410-421.

Ravald, A., \& Grönroos, C. (1996). The value concept and relationship marketing. European journal of marketing, 30(2), 19-30.

Roig, J. C. F., Garcia, J. S., Tena, M. A. M., \& Monzonis, J. L. (2006). Customer perceived value in banking services. International Journal of Bank Marketing, 24(5), 266-283.

Roselius, T. (1971). Consumer rankings of risk reduction methods. The journal of marketing, 35(1), 56-61.

Sweeney, J.C., Soutar, G.N., \& Johnson L.W. (1999). The role of perceived risk in the quality-value relationship: A study in a retail environment. Journal of Retailing, 75(1), 77-105.

Sun, H., \& Su, Z. (2012). New Thoughts of Customer Value Study. Physics Procedia, 24, 1232-1237.

Tuškej, U., Golob, U., \& Podnar, K. (2011). The role of consumer-brand identification in building brand relationships. Journal of Business Research.

Van Belleghem, S. (2010). Social media around the world. InSites Consulting.

Walker, R. H., Johnson, L. W., \& Leonard, S. (2006). Re-thinking the conceptualization of customer value and service quality within the service-profit chain. Managing Service Quality, 16(1), 23-36.

$\mathrm{Wu}, \mathrm{W}$. W. (2010). Linking Bayesian networks and PLS path modeling for causal analysis. Expert Systems with Applications, 37(1), 134-139.

Woodall, T. (2003). Conceptualising 'value for the customer': an attributional, structural and dispositional analysis. Academy of Marketing Science Review,12(1), 1-42.

Woodruff, R. B. (1997). Customer value: the next source for competitive advantage. Journal of the academy of marketing science, 25(2), 139-153. 
Yaşlıoğlu, M., Çalışkan, B. Ö. Ö., \& Şap, Ö. (2013). The Role of Innovation and Perceived Service Quality in Creating Customer Value: A Study on Employees of a Call Center Establishment. Procedia-Social and Behavioral Sciences, 99, 629-635.

Zeithaml, V. A. (1988). Consumer perceptions of price, quality, and value: a means-end model and synthesis of evidence. The Journal of Marketing, 52(3), 2-22.

Zhang, L., Tan, W., Xu, Y., \& Tan, G. Dimensions of Consumers' Perceived Risk and Their Influences on Online Consumers' Purchasing Behavior.Communications in Information Science and Management Engineering, 2(7), 8-14. 